\title{
The Study of Influential Integrated Marketing Communication on Iranian Consumer Buying Behavior for Imported Branded Cars: Datis Khodro
}

\author{
Alireza Miremadi ${ }^{1,2}$, Mahsa Samsami ${ }^{3}$, Alireza Eftekharian Qamsari ${ }^{3}$ \\ ${ }^{1}$ Advisory Council of Marketing Practitioners (ACMP), Canada \\ ${ }^{2}$ Former Dean \& Assistant Marketing Professor at Graduate School of Management at Sharif University of \\ Technology -International Campus, Iran \\ ${ }^{3}$ Master of Business Administration (Marketing) - Tehran University- International Campus, Iran \\ Correspondence: Alireza Miremadi, Advisory Council of Marketing Practitioners (ACMP), Canada.
}

Received: August 28, 2017

Accepted: November 6, $2017 \quad$ Online Published: November 8, 2017

doi:10.5539/ibr.v10n12p148

URL: https://doi.org/10.5539/ibr.v10n12p148

\begin{abstract}
The automobile industry especially imported cars are the most lucrative sector in Iranian market since the disposable income in both urban and rural are increasing and easy alternative finance being provided by all Iranian financial institutions are developing, furthermore imported cars are considered as a short-term investment among the consumer in Iranian market due the foreign currency fluctuations. This study is considered as the first research to review the consumer buying behavior about imported cars and how Datis Company advertise, promote and what is the best place to be advertised to convince customers to buy or try new cars in the Iranian market. Promotional mix have the consequence of creating brand images and symbolic appeals that can be the effective way to strike the responsive chord with consumers. The purpose of this paper is to examine the consumer buying behavior about the imported car through various IMC tools, discover most efficient place , most influential advertising message and how often consumers decide to change the car to better or new one in the Iranian market. A simple random sampling was selected as the sampling method. The customers of Datis Company (Previous Purchase) were sampled to respond to the online questionnaires and 197 questionnaires were returned providing an $89.5 \%$ response rate. We initiated with conducting an exploratory research on Iranian consumer behavior to determine the most important attribute adopted by them. The regression method applied to understand the influence of independent variables (Advertising, WOM, Internet Marketing, Direct Marketing, Public Relations, and Sales Promotion) on the dependent variable (IMC) in Datis Company. Above all, online marketing Communication (OMC), web and social network is discovered as the most effective way of placing the advertisement for Datis Company in the Iranian market. The findings of this study provide managerial implications for marketers for the advertising practice of technologically advanced products. The ambiguous results of the analysis suggest that companies should put more emphasis on the selection of the communicated information content of their advertisements.
\end{abstract}

Keywords: consumer behavior, IMC, OMC, advertising, Iranian market

\section{Introduction}

For most of the people, purchasing a car is the second most important and expensive decision next to purchase of a house for the automotive manufacturers, first-time car buyers give them the opportunity to create positive brand image which definitely could be reflected in next coming years because consumers could make repeat car purchasing. The concept of buying behavior is of prime importance in marketing and has evolved over the years. It is very important to understand consumer buying behavior as it plays a vital role while purchasing products. Day to day human want $\mathrm{s}$ are growing, expectation is growing. Car Models are no exception to this behavior. Consumer behavior is fairly complex as Car Purchase implies a high level of social and psychological involvement. Consumer buying behavior is a blend of Economic, technological, political, cultural, demographic and natural factors as well as Customer's own characteristics which is reflected by his attitude, motivation, perception, personality, knowledge and lifestyle. Integrated Marketing Communications tools consist of sales promotion, advertising, direct marketing, internet marketing, public relations and personal selling. As you know 
advertising is paid to introduce our organization, product, services, and idea. This communication tools will have beneficial and critical consequences on customer mind especially consumer behavior. Certainly, advertising is considered to be the most effective communication tools. There is a wide range of investigation due to effective advertising(Nikhil \& Bhunvender, 2012). Whereas there is a considerable demand for imported cars in Iran and this action is increasing annually, On the other hand, We can find different and numerous company which has wide ranging duties in the field of importing, selling and leasing agency. Undoubtedly competitive market between these kinds of companies leads integrated marketing communication especially advertising to critical tools for attraction consumer on purchasing. The purpose of this paper is an evaluation of the effective advertising dimensions to customer's attraction in order to purchase imported car in Iran. Our case study is Datis khodro Company in Iran . Consumer behavior consists of all human behavior that goes in making and post purchase decision . one can succeed in the competitive market only after understanding the complex consumer behavior an understanding of the consumer enables a marketer to take marketing decisions which are compatible with its consumers need in automobiles market around the world (Vikram 2014).

\subsection{Datis Khodro Company}

Datis Khodro company was established in 2013 and relying on 12 years' experiences of its managers to import and sales of luxury cars, it Intends to create a new point of view for the customers. The main activity of the company is import and sales the stylish cars. Providing the consultancy services to obtain the best choice in addition to timely fulfillment obligations let the Datis khodro to find the significant place in the competitive vehicle market. Datis khodro would like to reach the main and defined goal and better progress so this company was built the major fundamental as the table 1 .

Table 1. Major Fundamental of Datis Khodro

\begin{tabular}{ccc}
\hline No & Subject & Features \\
\hline 1 & Headquarter (Head Office) & In Tehran (600sqm) \\
2 & Central showroom for services & In Tehran (1000sqm) \\
3 & Central workshop for services & In Tehran(3000sqm) \\
4 & dealers for sales and after sales-services nationwide & More than 10 \\
\hline
\end{tabular}

Datis khodro company is the holding company as following:

I. Datis Tejarat Mandegar,. Tehran Iran (Import, sale and service of all products)

II. Datis Co. Ltd., Yerevan- Armenia (Import and export cars)

III. Datis is pressing the registration in Hamburg-Germany (Import and Export from Europe, financing requirements of the holding main customer.

The business of Datis Company lines is including import vehicles such as car, heavy cars, motorcycle, bike, E-bike, spare parts, consumable parts, and so on. In addition brands which is imported and sold such as Toyota, Lexus , Kia Motors , Hyundai, BMW, Mercedes in Iranian market.(Datis 2013 )

\subsection{Datis Sales Revenue for Major Imported Cars}

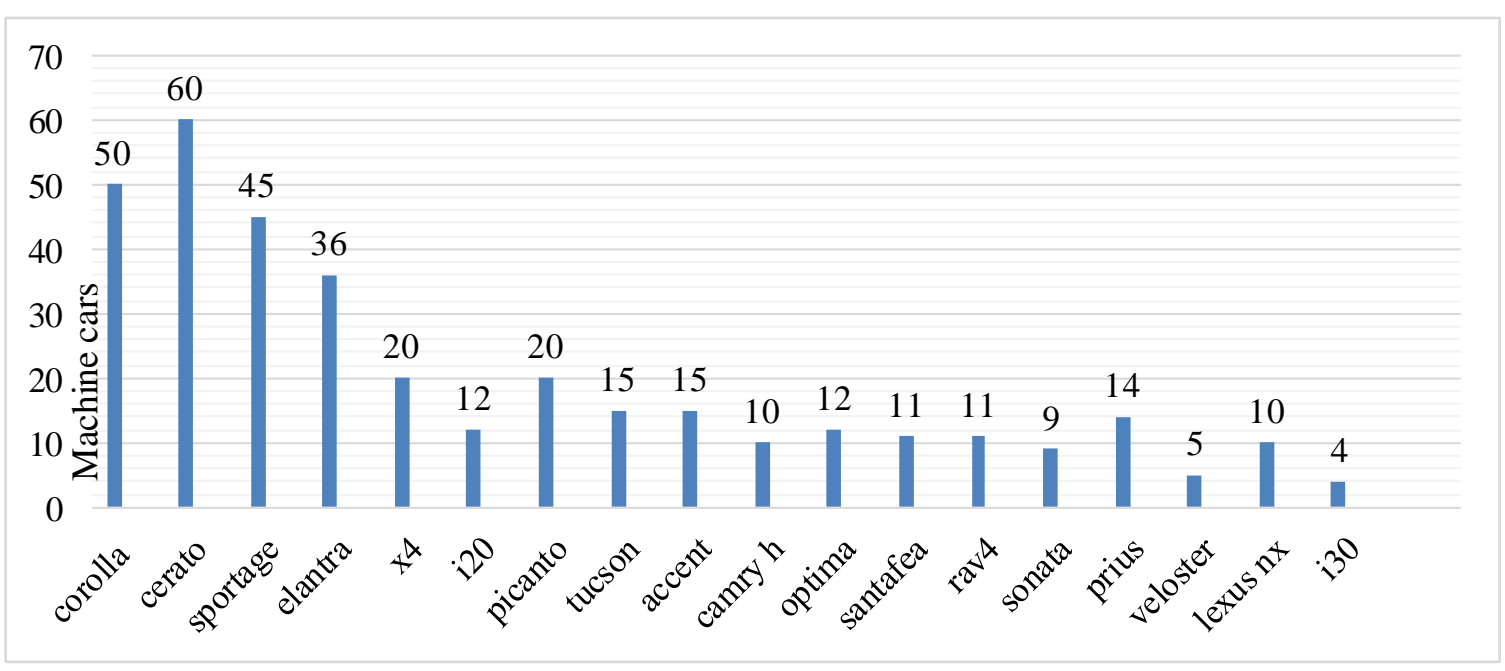

Figure 1. Sales Amount Of Datis Khodro For Imported Cars in 2016 


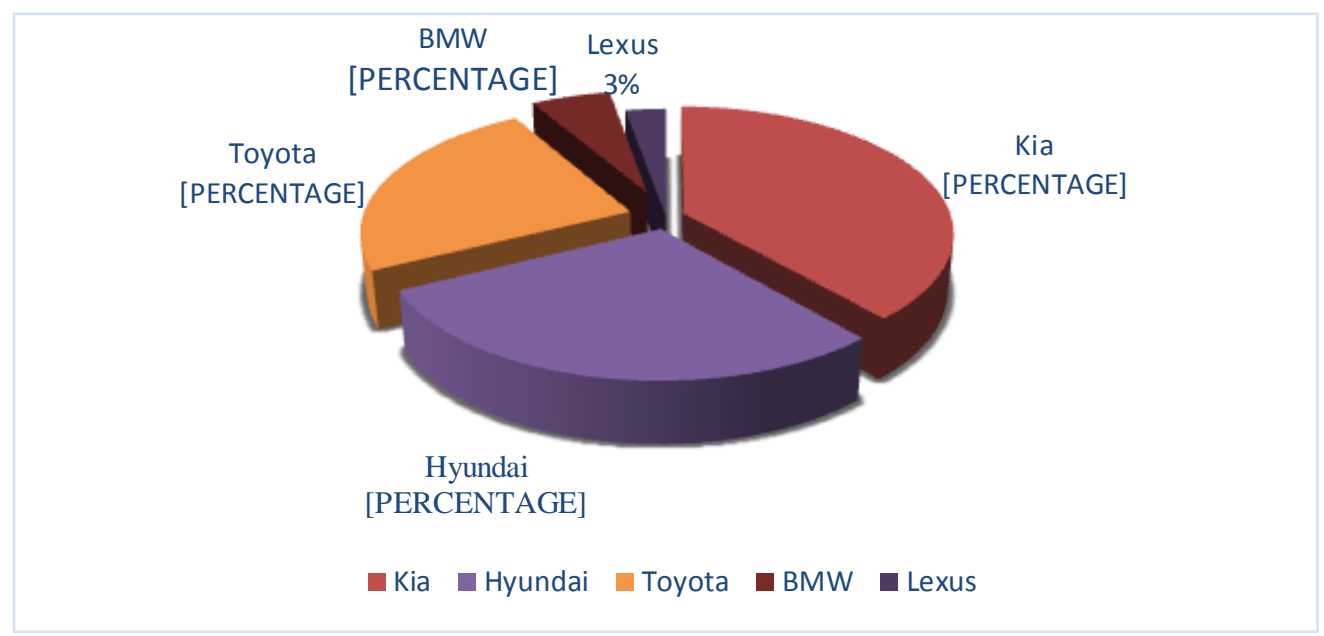

Figure 2. Sales Volume Based on Imported branded Car through Datis khodro

\subsection{The Need of Study}

Due to the emergence of globalization and liberalization there is a stiff completion among the Automobile industries which are focusing attention in capturing the Iranian markets. Customers have now changed their attitude that yesterday's luxuries are today's necessities. To be a successful marketer it is absolutely essential to study the consumer buying behavior and perceptions of the prospective buyers and track their drivers of those perceptions. Unfortunately, the manufacture of the domestic car can't fulfill the customer needs and expectations so the tastes of Iranian customers are gradually shifted from domestic cars to imported cars. Datis is a pioneer in importing branded cars and trying to fulfill this gap in the Iranian market. Datis company imported cars Company is trying to fulfill the existing gap between domestic cars with the imported one. The experimental data are rather controversial and there is no general agreement about studying the customer perception regards imported cars, therefore the literature reviews are really limited in this existing scenario

\section{Literature Review}

The automobile industry especially imported cars is the most lucrative sector in Iranian market since the disposable income in both urban and rura are increasing and easy alternative finance being provided by all Iranian financial institutions are developing, furthermore imported cars are considered as short-term investment among the consumer in Iranian market due the foreign currency fluctuations and domestic automobile industry are not comparable with imported cars.. This study is considered as the first research to review the consumer buying behavior about imported cars and how we advertise, promote and what is the best message can convince customers in the Iranian market. It also equips the Datis khodro to take advantage of various promotional, message creation methods and marketing techniques to increase the chance of grabbing the customers.(Miremadi, 2012). Concerning advertising and effect of this on customer awareness and image, We could collect plenty of investigation and studies. Studies are illustrated five vital communications function of advertising as following: Informing, Influencing, Reminding and increasing salience, adding value and assisting other company efforts. The first function of advertising is related to informing in which advertising leads the cons umer to aware of the new brand, educates them in order to brands' benefits, features and so on. Another function of advertising is proven to be influenced by which companies and sellers could have important consequences for choosing one brand versus another not only primary demand but also the secondary brand. A brand will be reminded and fresh in the consumers' mind by advertising, in addition, this function has been pertained to as making a brand salient. Undoubtedly effective advertising also increments the consumers' preference and interest in the mature brand and furthermore this IMC tool has been corroborated to consequence brand switching by reminding consumers. Improving quality, innovating and altering consumer perception is the new offer and unique selling proposition which are demonstrated to add value by producer and an effective advertising will cause to illustrate these adding value. When consumer used to be identified product packages by advertising, certainly this process could assist salesperson and will declining costs due to answering consumers' expectation on television or others medias and medium vehicles. Assisting other company efforts is last but not list of adverting functions. (Shimp \& Andrews, 2012, p. 276).In fact, some advertising experts contend that advertising is most effective when it reflects both ends of the creative advertising continuum that is, by addressing not only functional product benefits but also symbolic or psychosocial benefits.(Shimp \& Andrews, 2012). 
Table 2. Various Research and Study in Advertising Methods

\begin{tabular}{|c|c|c|}
\hline Year & Author & Description \\
\hline 2017 & $\begin{array}{c}\text { (Acar \& } \\
\text { Temiz) }\end{array}$ & $\begin{array}{l}\text { Advertising effectiveness on financial performance of banking sector is studied . The result of } \\
\text { this case is displayed significant and positive association between advertising expenses and } \\
\text { financial performance long term by advertising. Additionally effectiveness advertising will } \\
\text { bring accounting and amortization policy toward their expenses on mind. }\end{array}$ \\
\hline 2014 & $\begin{array}{l}\text { (Hadadi \& } \\
\text { Almsafir) }\end{array}$ & $\begin{array}{l}\text { One of the marketing strategies is advertising through media that plays a substantial role in } \\
\text { illustrating the merits and demerits aspects of products and services to the audiences. } \\
\text { Absolutely advertising as integrating marketing communication is so costly but companies can } \\
\text { only reach positive effects by arranging their advertisements budgets wisely. In order to avoid } \\
\text { expensive costs, marketers will can evaluate the impact of online advertising on sells. }\end{array}$ \\
\hline 2012 & $\begin{array}{l}\text { (Shimp \& } \\
\text { Andrews) }\end{array}$ & $\begin{array}{l}\text { Some advertising experts contend that advertising is most effective when it reflects both ends of } \\
\text { the creative advertising continuum that is, by addressing not only functional product benefits } \\
\text { but also symbolic or psychosocial benefits. }\end{array}$ \\
\hline 2011 & $\begin{array}{l}\text { (Ha, John, } \\
\text { Janda, \& } \\
\text { Muthaly) }\end{array}$ & $\begin{array}{l}\text { Advertising would affect brand loyalty via satisfaction, perceived quality, in addition indirectly } \\
\text { this IMC tools would have efficacy on brand loyalty through affecting image and conviction } \\
\text { stages of the communication process (as opposed to the preliminary attention stage). } \\
\text { Advertising follows from the fact that personalities are particularly useful for the creation of } \\
\text { brand associations. Brand associations influence the "evaluation of alternatives" stage in basic } \\
\text { consumer buying behavior models. }\end{array}$ \\
\hline 2007 & $\begin{array}{c}\text { (Rajagopal \& } \\
\text { Gopal) }\end{array}$ & $\begin{array}{l}\text { Effective brand management, encompassing brand personality, is of paramount importance in } \\
\text { reaching the overall company goals towards satisfaction, loyalty, and profitability. }\end{array}$ \\
\hline 2006 & (Rajagopal) & $\begin{array}{l}\text { Advertising plays an important role in reinforcing perceived performance and usage experience } \\
\text { of a particular brand. }\end{array}$ \\
\hline 2002 & Idsmith \& Laffer & $\begin{array}{l}\text { Internet is one of the impressive tools of advertising in which we can find a wide range of both } \\
\text { positive and negative points for producers and sellers until moving consumer to purchasing. } \\
\text { Internet advertising include two chapters in which can be viewed Offline traditional media } \\
\text { advertising similar to TV, newspaper and so on. Another chapter is pertained to online } \\
\text { advertising as Email, website, social network and something like that. }\end{array}$ \\
\hline 2000 & $\begin{array}{l}\text { (Greuner, } \\
\text { Kamerschen, } \\
\text { \& Klein) }\end{array}$ & $\begin{array}{l}\text { In the past studies discovered relationship between advertising and profits. By the way } \\
\text { advertising is treated an investment, overstating the real rates of return to advertising. } \\
\text { Advertising on competition in the US automobile industry such as General Motors, Ford, and } \\
\text { Chrysler over the } 25 \text {-year period from } 1970 \text { to } 1994 \text {. Subsequently they could support the view } \\
\text { of advertising by which car industry market is more competitive. The result show that } \\
\text { advertising is effectiveness in this industry. }\end{array}$ \\
\hline 1993 & (Kwoka) & $\begin{array}{l}\text { Regarding the competitive issues, the sales effects of own advertising and style change make } \\
\text { clear that these strategies are advantageous to each seller individually. Substantively sizeable } \\
\text { positive effects from style change, model age, and advertising in US car models over a } 22 \text {-year } \\
\text { period. Advertising and style change each increases a model's sales. In addition th is action is } \\
\text { proven to be short-lived but styling has a much longer impact }\end{array}$ \\
\hline 1993 & (Bendixen) & $\begin{array}{l}\text { The influence of advertising is related to products and services with low consumer involvement } \\
\text { such as foodstuffs, cigarette and something like that. Advertising would play a remarkable role } \\
\text { at attraction consumer. Although content of advertising is so important, undoubtedly advertising } \\
\text { in different media and mediums will have different consequences. }\end{array}$ \\
\hline 1971 & $\begin{array}{l}\text { (Cowling \& } \\
\text { Cubbin) }\end{array}$ & $\begin{array}{l}\text { In order to investigating price, quality and advertising competition in United Kingdom Car } \\
\text { Market examined that the behavior of advertising appropriations is consistent with long-term } \\
\text { rule-of-thumb behavior, which directly relates advertising appropriations to sales revenue, } \\
\text { coupled with a short-run compensatory mechanism, whereby a reduction in market share } \\
\text { generates an increase in advertising appropriations. }\end{array}$ \\
\hline
\end{tabular}




\subsection{Major Players in Iranian Automobile Industry}

Table 3. Major Player in Iranian Automotive Industry

\begin{tabular}{|c|c|c|}
\hline Company & History & $\begin{array}{c}\text { Bestselling } \\
\text { product }\end{array}$ \\
\hline & $\begin{array}{l}\text { To found in August } 1962 \text {. To sign a contract with the English company for 'Paykan'. } \\
\text { In late 1977, the company held talks with France's Peugeot to replace Paykan. In } \\
2003 \text {, Pars and Samand models of the year and Peugeot } 206 \text { sedan were put into } \\
\text { production. In 2004,the two sedans of Pars ELX and Samand Lx were introduced to } \\
\text { the market. In 2006, the national engine production line and Samand sedan } \\
\text { production lines in Azerbaijan, Belarus and Syria were put into production. In 2008, } \\
\text { IKCO designed Runna. }\end{array}$ & $\begin{array}{c}\text { Peugeot405 } \\
\text { Peugeot206 } \\
\text { Peugeot Pars } \\
\text { Samand } \\
\text { Dena }\end{array}$ \\
\hline & $\begin{array}{l}\text { SAIPA was established in 1966, with } 75 \% \text { Iranian ownership. In 1968, Producing } \\
\text { Dyan models. Producing pickup with } 2000 \mathrm{cc} \text { displacement in 1983. Producing } \\
\text { Renault } 21 \text { in 1993. In 1994, Producing various Models of "Carburetor-Engined } \\
\text { Pride". In 1999, Producing Pride Safari. Localization of parts; } 81 \% \text { for Pride, } 79 \% \text { for } \\
\text { Nissan pickups. In 2002, Launching and Producing SAIPA 141. In 2005, Launching } \\
\text { Rio Production Line. In 2007, Launching Tondar } 90 \text { in } 3 \text { Types. Launching SAIPA } \\
\text { 132. In 2012, Introducing of } 3 \text { new models: TIBA2, SAIPA } 151 \text { and Automatic } \\
\text { X100. In 2014, Launching TIBA2 Production Line in SAIPA. Launching Kia Cerato } \\
\text { Production Line in SAIPA. Launching ARIO Experimental Production Line in } \\
\text { BONRO. In 2016, Joint-Venture of SAIPA and Citroën (SAIPA Kashan).Launching } \\
\text { CS35. Launching Renault Sandero Step way. Launching CERATO Optional. } \\
\text { Launching Quick. }\end{array}$ & $\begin{array}{c}\text { Tiba } \\
\text { Saipa } 131\end{array}$ \\
\hline Modir & $\begin{array}{l}\text { Modiran Vehicle Manufacturing Company is an Iranian automobile firm that } \\
\text { currently makes a version of the Chery QQ3 called the MVM in } 2001 \text {. }\end{array}$ & $\begin{array}{c}\text { MVM } \\
\text { chery tigo5 }\end{array}$ \\
\hline DDRO & $\begin{array}{l}\text { Pars Khodro was the first manufacturer of sport utility vehicles in Iran. 1968- 1978, } \\
\text { Industrial co-operations of GM as a shareholder. Renaming Jeep co-investor Co. to } \\
\text { 'Iran GM'. Launching new products :'Chevrolet Iran' (Opel), 'Chevrolet Pickup', } \\
\text { 'Chevrolet Nova', 'Buick Sky Lark', and 'Cadillac Civil'. 1986-1990, nitiation of } \\
\text { co-operations with Nissan Japan. Additional options of Army equipment to Jeep. } \\
\text { Launching the production lines Nissan Patrol with variety of models (Van, Hard Top, } \\
\text { Ambulance). 1995-1999, Transferring Renault } 5 \text { production line from Saipa to Pars } \\
\text { Khodro. 2000-2004, Saipa Purchasing 51\% of Pars Khodro shares in Tehran Stock } \\
\text { Market. 2005-2011, Purchase of Zagros Khodro Co. by Pars Khodro Co. and } \\
\text { transferring Pickup \& Roniz production lines from PK to Zagros Khodro. Initiating } \\
\text { the production of Renaults France new cars including Megane and Logan (by the } \\
\text { trading name of Tondar 90). }\end{array}$ & Tondar 90 \\
\hline Bahman & $\begin{array}{l}\text { Bahman Motor Company Bahman Motor Company was founded in } 1952 \text { under the } \\
\text { title of Iran Khalij Co. and increased range of products to Mazda } 1000 \text { with cargo } \\
\text { capacity of } 500 \mathrm{Kg} \text { and Mazda } 1600 \text { with cargo capacity of } 1 \text { Ton. Changing the } \\
\text { name to Bahman Group and signing a contract with the Japanese Motors company } \\
\text { Mitsubishi in } 2002 \text {. In } 2003 \text { Bahman Group, with the launch of Mitsubishi Pajero } \\
\text { entered to 4WD market. In } 2008 \text { a new passenger car" Mazda 3" and" Capra } 1600 " \\
\text { double cap pickup were produced and released to the market. In year } 2010 \text { new } \\
\text { "Mazda 2", "Mazda3" and "Capra" pickup were lunched into market and also on the } \\
\text { same year Bahman Motor Center. Year } 2011 \text { began with production of Mazda } 1600 \\
\text { passenger vehicle, sedans B50, and Mini-track. Eventually in year } 2012 \text { Bahman } \\
\text { Motor Center became independent company under Bahman Motor Co. }\end{array}$ & Mazda 3 \\
\hline $\begin{array}{c}\text { Kerman } \\
\text { Automotive }\end{array}$ & $\begin{array}{l}\text { Kerman Group started its activities on January of } 1990 \text {. Kerman Khodro started its } \\
\text { activity in the field of importing various models of Daewoo vehicles, After } \\
\text { outstanding welcome by customers form our products in order to reach our primary } \\
\text { objects, absorb fore ign investment and take position in the cycle of vehicle } \\
\text { production, execute vehicle production design in Arg e Jadid.Executive operation of } \\
\text { this project was started in } 1993 \text { and its result was creating various companies and } \\
\text { assembly of vehicles like Kerman Motor, Rayen Vehicle Making, Bam Vehicle } \\
\text { Making. }\end{array}$ & $\begin{array}{c}\text { JAC S5 } \\
\text { Lifan } 820\end{array}$ \\
\hline
\end{tabular}

The primary objectives of advertising are to create awareness among the target consumers. Undoubtedly controlling time of advertising has critical consequences on budget constraints. So companies need to identify reach and frequency. Reach and frequency is well-established marketing metrics for planning and evaluating the effectiveness of advertising campaigns.

Actually, companies have diverse type of advertising though they need to stablish a suitable schedule via advertising technique. Reach and frequency are proven to an important technique. In major, frequently purchased 
packaged goods markets, returns to advertising diminish fast. A small frequency, therefore (one to three reminders per purchase cycle), has an sufficient and important role in advertising an awareness and established brand.(Turner, Hojjat, Cetintas, \& Yang, 2016), (Vakratsas \& Ambler, 1999).There is several technique for achieving effectiveness advertising. The first technic is pertained to placing advertisement in prime time commercials. An another technic refers to placing ads in large circulation general interests magazines. last but not least is appropriate to using multiple network ,stations, many national news, papers simultaneously. In spite of this, If we would like to present a beneficial advertising when frequency is emphasized as primary goal of media plan and reach as secondary target, we have to place advertising in late night TV program, use experience magazines, sponsorship of major events and something like that.

Table 4. Type of Advertising Techniques

\begin{tabular}{|c|c|}
\hline Type of advertising & Description \\
\hline Online Advertising & $\begin{array}{l}\text { Advertising via internet (World Wide Web).* } \\
\text { - AdSense (These are the ads served to consumers via Google, by showing ads relevant to the } \\
\text { information on any page.) } \\
\text { - Email advertising (and SPAM) } \\
\text { - Native Advertising (This continues to grow and dominate the online advertising space.) } \\
\text { - Facebook Ads } \\
\text { - YouTube Ads } \\
\text { - Sponsored Tweets } \\
\text { - Website Takeovers } \\
\text { - Rich Media Ads } \\
\text { - Pop Up Ads (and pop-under) } \\
\text { - Pre-video ads } \\
\text { - Blogging } \\
\text { Banners ads (These include skyscrapers, full banners, squares, and buttons.) }\end{array}$ \\
\hline $\begin{array}{l}\text { Cell Phone \& Mobile } \\
\text { Advertising }\end{array}$ & $\begin{array}{l}\text { This advertising is similar to online advertising but It can be better that is utilize due to all of } \\
\text { applications in which use cell phones, iPads, Kindles, Nooks, and other portable electronic } \\
\text { devices with Internet connectivity. } \\
\text { Current trends in mobile advertising involve major use of social media such as Twitter, } \\
\text { Instagram, Snapchat, and Facebook }\end{array}$ \\
\hline $\begin{array}{l}\text { Public Service } \\
\text { Advertising }\end{array}$ & $\begin{array}{l}\text { Public Service Advertisements (PSA)s traditionally appear on TV and radio, but are also being } \\
\text { promoted online in nowadays. }\end{array}$ \\
\hline Print Advertising & $\begin{array}{l}\text { Before digital advertising one of the effectiveness advertising is proven to be print advertising } \\
\text { in which is split into three sub-categories, such as: } \\
\text { - periodical advertising (a magazine, a newspaper, or anything else that comes out at regular } \\
\text { intervals) } \\
\text { - Brochures, } \\
\text { - Leaflets } \\
\text { - Flyers } \\
\text { - Handouts } \\
\text { - Direct mail advertising. }\end{array}$ \\
\hline Outdoor Advertising & $\begin{array}{l}\text { This type of advertising is known all of ads when people is Out Of Home }(\mathrm{OOH}) \text {. } \\
\text { - Billboards } \\
\text { - Bus shelter posters } \\
\text { - Fly posters } \\
\text { - Even those big digital boards in squares and highway } \\
\text { - Even shopping centers are some of type outdoor advertising. }\end{array}$ \\
\hline Broadcast Advertising & $\begin{array}{l}\text { The term broadcast advertis ing applies to commercials aired on either te levision or radio, which } \\
\text { are typical called spots. }\end{array}$ \\
\hline guerrilla Advertising & $\begin{array}{l}\text { Innovation and ideas is created guerrilla advertising even without a large budget. It will happen } \\
\text { via word of mouth and social media }\end{array}$ \\
\hline
\end{tabular}

(Maclnnis \& Jaworski, 1989) find that emotional advertisings are more likely to generate sales than ads based on informative content.(Ndubisi, 2007) find that marketers can defer advertising wear-out effects, or the "decreasing response to an advertising with improving repetition of display to the advertising", by offering emotional content. On the whole, most of studies is shown that appropriate advertising content moderates the effect of ad spending on sales and decision purchasing. (Becker, 2017).Print advertisements could have greater attention since this type of advertising usually consist of text or a single picture. On the other hand TV advertisements include a wide range of picture series pictures. So this type is more complex for analysis than. Cross-cultural studies focused on the differences in content in terms of advertising expression. Content of advertising could takes shape by means of nostalgic appeal, use of music, animations, role of women and ambient advertising (Srivastava et al., 2017). Several goals of content of advertising will be matched by correct and false ad recognition, subjective ad 
comprehension, perceived advertiser awareness to viewers' needs, ad involvement, and overall ad persuasion. (Bishop, Brocato, \& Vijayalakshmi, 2017)

\section{Research Methodology}

The purpose of this study is to elaborate the Datis consumer buying behavior for imported car through various IMC tools in Iranian market, In other words, the aim is to answer the following research objectives:

RQ1: To determine the most influential Integrated marketing communication techniques on consumer buying behavior about imported cars by Datis Company.

RQ2: To Examine and analyze the advertisement influences outcome created by datis company to motivate customer to buy imported car in Iranian market.

RQ3: Determine the customer perception about integrated Marketing Communication on introducing new imported cars by Datis company.

RQ4: To Highlight the importance of brand awareness and brand association in Datis company

The research started with conducting an exploratory research on Iranian consumer behavior to determine the most important attribute adopted by them. The research gradually shifted from exploratory research to quantitative. Through literature review and conducting deep interviews with the experts in Iranian automobile industry, we have divided the questionnaire into four sections. The method of distribution questionnaire was through online methods for Iranian customer in Datis Company. The first section, we asked about demographic information of the respondents, the second section, the respondents asked about the Promotion Place and main of objective of the unique message and attractive IMC technique towards them. The third section is about the various IMC attributes, determining the Reach and Frequency techniques and the last part we asked about the brand association and brand awareness, furthermore, the questionnaire used five points Likert scale. The respondents were asked to reflect the amount of measured variable from completely agree to completely disagree.

\subsection{Research Approach}

There are two Scientific approaches when writing an executive study, a deductive and an inductive . using an inductive approach means that the researcher gather data and develop theory by analyzing it usually of a qualitative nature . using deductive approach is associate with building and testing of hypothesis and is more concerned with achieving results which can be generalized, usually of a quantative nature .(Saunders \& Thornhill, 2007). This Study is based on deductive approach .

In this research, a simple random sampling was selected as the sampling method. The customers of Datis Khodro (Previous Purchaser) were sampled to respond to the questionnaires. the research is executed in Tehran as main and accessible province in Iran . To achieve a diverse response from a expand the scope of ideas, age, education, income and type of occupation used. According to (Fisher, 2007), the number of distributed questionnaires will have to be larger than the minimum required and the response rate of $30 \%$ is considered very well. In this study, 220 questionnaires were distributed online through http://fa.datiskhodro.com/HomeS/CustomerClub and 197 questionnaires were returned providing an $89.5 \%$ response rate. There are two important concepts one should keep in mind when writing a report, validity, and reliability. Validity is the ability of a chosen instrument to measure what it is supposed to measure. Reliability is the extent to which research results would be stable or consistent if the same techniques were used repeatedly. The role of reliability is to minimize the errors and biases in a study In this research reliability were assessed by the method of alpha Cronbach. the internal consistency is calculated to 0.843 . Since alpha Cronbach is more than 0.7 ; reliability of trust measure is acceptable. Indicator reliability means the extent to which a variable or set of variables is consistent regarding what it intends to measure the face validity and content validity is performed in this study. 


\section{Data Anal ysis and Interpretation}

4.1 RQ1: To Determine the Most Influential Integrated Marketing Communication Techniques on Consumer Buying Behavior about Imported Cars by Datis Company

Table 5. Regression Model Summary For IMC In Datis Khodro

\begin{tabular}{ccccc}
\hline Model & $\mathrm{R}$ & R Square & Adjusted R Square & Sig \\
\hline 1 & $.723^{\mathrm{a}}$ & .522 & .516 & .000 \\
2 & $.835^{\mathrm{b}}$ & .698 & .690 & .000 \\
3 & $.900^{\mathrm{c}}$ & .809 & .802 & .000 \\
4 & $.950^{\mathrm{d}}$ & .902 & .897 & .000 \\
$\mathbf{5}$ & $\mathbf{. 9 8 3}^{\mathrm{e}}$ & $\mathbf{. 6 6 6}$ & $\mathbf{. 9 6 4}$ & $\mathbf{. 0 0 0}$ \\
6 & $1.000^{\mathrm{t}}$ & 1.000 & 1.000 & $.016 .{ }^{\mathrm{g}}$ \\
\hline
\end{tabular}

e. Predictors: (Constant), Advertising, WOM, Internet Marketing, Direct Marketing, Public Relation

f. Predictors: (Constant), Advertising, WOM, Internet Marketing, Direct Marketing, Public Relation, Sales Promotion

Since the Sig value of all independent variables except the sale promotion is less than .005 , therefore, all independent variable participate in predicting the dependent variable (IMC) in Dais Company. The IMC result can predict with Advertising, WOM, Internet Marketing, Direct Marketing, and Public Relation. The regression model summary proved that $\% 96.4$ of IMC is completely depended on performing the precise techniques of Integrated marketing Communication .

4.2 RQ2: To Examine and analyze the advertisement influences outcome created by datis company to motivate customer to buy imported car in Iranian market .

Table 6. Advertisement Influences On Customers in Datis Company

\begin{tabular}{|c|c|c|c|}
\hline \multicolumn{2}{|c|}{ Advertisement Influences } & Percentage & Influencing Ranking \\
\hline \multirow{6}{*}{ 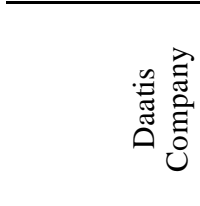 } & Reminder & 15.0 & 4 \\
\hline & Effectiveness & 31.0 & 1 \\
\hline & Intimate and valid & 24.0 & 3 \\
\hline & Reasonable & 26.5 & 2 \\
\hline & Confuse & 2.0 & 5 \\
\hline & Total & 98.5 & \\
\hline
\end{tabular}

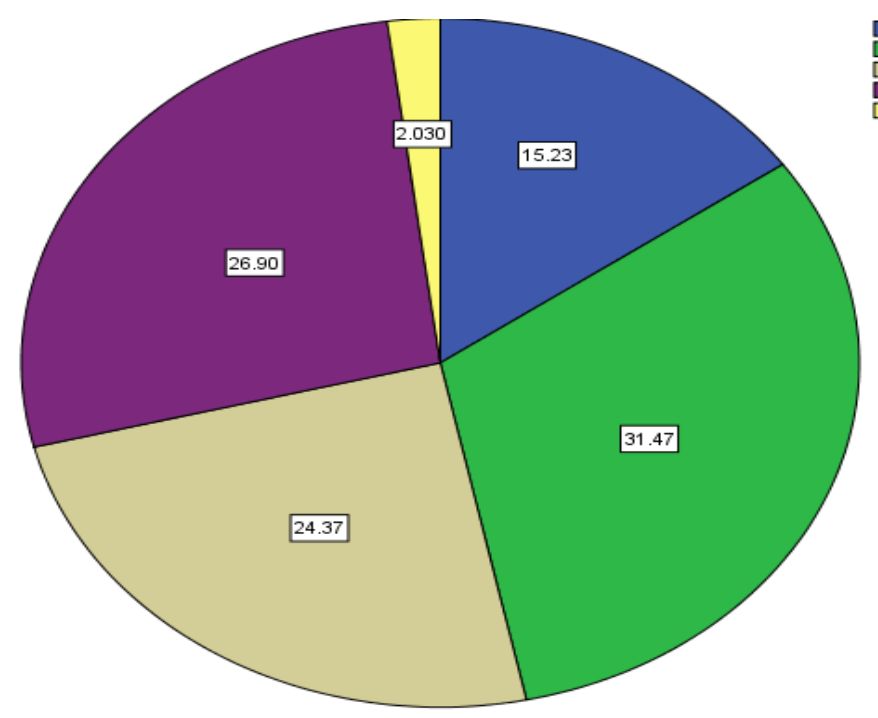

Figure 3. Advertisement Influences OutCome In Datis Copmany

The data would seem to suggest that effectiveness (\% 0.31) followed by reasonable(\%.0.26.5) and intimate and $\operatorname{valid}(\% 0.24)$ are most important and essential outcomes of Advertising Campaign that Datis company should be executed since customer expect it from advertisement message from company to introduce new imported cars. It is generally accepted that the web and social network or online advertising(online Marketing Communication) (61 \%), TV(16.7\%), News Paper and Magazine (8.7\%), Showroom (7.9\%) and Billboard(5.6 \%) are most important promotional places to advertise for current and new imported cars for datis company among the Iranian customers, furthermore the web and social network is the quickest best way to achieve USP from 
advertisement message outcome whereas the TV is working to persuade customer to buy imported cars from Datis company. It is also worth mentioning that billboard is best tools to motivate customer to buy the Datis Company products. As matter of fact, the web and social network or online advertising is becoming the major place for any company if they really want to survive in the electronic and digital world.

4.3 RQ3: Determine the Customer Perception about Integrated Marketing Communication on Introducing New Imported Cars by Datis Company

Table 7. Priorities Of IMC Techniques

\begin{tabular}{cccc}
\hline IMC Techniques & Mean Rank & Ranking Priorities & Customer Opinion \\
\hline Direct Marketing & 3.99 & 1 & Very Strong \\
WOM & 3.99 & 1 & Very Strong \\
Internet Marketing & 3.85 & 2 & Very Strong \\
Advertising & 3.63 & 3 & Strong \\
Public Relation \& Publicity & 3.09 & 4 & Moderate \\
Sales Promotion & $\mathbf{2 . 4 5}$ & $\mathbf{5}$ & Need To Improve A \\
\end{tabular}

Needless to say, Sales promotion is vital fact nowadays, therefore Marking Team of Dais khodro should concentrate more on various methods of Sales promotion. Strictly Speaking, Datis consumer didn't observe any Sales promotion activities from the marketing team to attract, motivate or even persuade them to think about the New products or the new version of old products. More relevantly, WOM and Direct marketing and internet marketing are working really fantastic in Datis Company.

4.4 RQ4: To Highlight the Importance of Brand Awareness and Brand Association in Datis Company

Table 8. Brand Association and Brand Awareness Priorities In Datis Khodro

\begin{tabular}{|c|c|c|c|c|c|}
\hline Brand Association & $\begin{array}{l}\text { Mean } \\
\text { Rank }\end{array}$ & $\begin{array}{c}\text { Ranking } \\
\text { Priorities }\end{array}$ & B rand Awareness & Mean Rank & $\begin{array}{c}\text { Ranking } \\
\text { Priorities } \\
\end{array}$ \\
\hline $\begin{array}{c}\text { Special } \\
\text { Advertisement }\end{array}$ & 2.66 & 1 & Datis Advertising Towards Informing & 2.69 & 1 \\
\hline $\begin{array}{c}\text { Favorable } \\
\text { Advertisement }\end{array}$ & 2.65 & 2 & $\begin{array}{c}\text { Advertisement Proved That We Know } \\
\text { The Datis Products are Very } \\
\text { Well-known }\end{array}$ & 2.64 & 2 \\
\hline $\begin{array}{l}\text { Advertising Towards } \\
\text { Purchasing }\end{array}$ & 2.62 & 3 & $\begin{array}{l}\text { Advertising z Showing highly security } \\
\text { of Datis Products }\end{array}$ & 2.35 & 3 \\
\hline Powerful Brand & 2.07 & 4 & $\begin{array}{c}\text { Several Thoughts Towards Datis } \\
\text { Advertisements }\end{array}$ & 2.32 & 4 \\
\hline
\end{tabular}

This table is quite revealing that Special advertisement that includes unique message has more priority in determining the Datis brand Association among the customer, whereas Iranian customers are interested in an advertisement with more informing knowledge in the Iranian market. The single most striking observation to emerge from data emphasizes on the Special advertisement to prevent customers from several thoughts from Dtais company Advertisements.

\section{Conclusions}

Appropriate marketing communication is critical for the success of a product. Especially in high-tech markets, the adoption of new products is challenging, as customers' willingness to buy a product can be hindered by a lack of knowledge and experience. The results provide practical insights into the advertising of technologically advanced products in a high-tech market, namely automobiles, furthermore, it indicates the promotional places that are associated with a perception of Iranian customers towards the new Imported cars by Datis company. It is strongly demonstrated that online marketing Communication (OMC) or online advertising, website, social network and virtual environment are strongly supported by customers. what is so surprising is that TV and Showroom are less popular in compared to online advertising when Iranian customer is thinking about imported cars by Datis company. The findings of this study provide managerial implications for marketers for the advertising practice of technologically advanced products. The ambiguous results of the analysis suggest that companies should put more emphasis on the selection of the communicated information content of their advertisements It emerges that Datis Marketing team should focus on effectiveness, reasonable and intimate and valid as an influential message out when they think about the creation of new advertisement. It is beyond doubt that IMC plays an essential role in motivating and persuading the customer to think or rethink about new imported cars by Datis company, therefore, they should concentrate on internet marketing as effective IMC tool among the target market and develop the reach techniques for the new customer in existing market for developing new products. There are grounds that for supporting that advertising has significant consequences on 
consumer buying through virtual environment, for the matter, Datis customer proved as powerful brand association, moreover adverting and advertisement towards purchasing as strong brand awareness of this company .the current study found that highly security of Datis product is an essential feature that they can easily be highlighted in their advertisement to achieve trust among the target market. Despite its interesting results, the study has some limitations, which have to be taken into account. The focus of this study was placed on a single industry, narrowing the generality of the results. Future studies could, therefore, conduct a cross-industrial comparison integrating different product categories.

\section{References}

Acar, M., \& Temiz, H. (2017). Advertising effectiveness on financial performance of banking sector: Turkey case. International Journal of Bank Marketing, 35(4). https://doi.org/10.1108/JJBM-03-2016-0036

Becker, M. (2017). Advertising effectiveness: the role of content. Universität zu Köln.

Bendixen, M. T. (1993). Advertising effects and effectiveness. European Journal of Marketing, 27(10), 19-32. https://doi.org/10.1108/03090569310045861

Bishop, M. M., Brocato, E. D., \& Vijayalakshmi, A. (2017). The role of medium content and ad format congruity in influencing advertising outcomes. Journal of Marketing Communications, 23(4), 371-384. https://doi.org/10.1080/13527266.2015.1033442

Cowling, K., \& Cubbin, J. (1971). Price, Quality and Advertising Competition: An Econometric Investigation of the United Kingdom Car Market. Economica, 38(152), 378-394. https://doi.org/10.2307/2551879

Datis , K. (2013 ). http://datiskhodro.com/Home/AboutUs. Retrieved from http://datiskhodro.com/

Goldsmith, R. E., \& Lafferty, B. A. (2002). Consumer response to web sites and their influence on advertising effectiveness. Internet Research, 12(4), 318-328. https://doi.org/10.1108/10662240210438407

Greuner, M. R., Kamerschen, D. R., \& Klein, P. G. (2000). The Competitive Effects of Advertising in the US Automobile Industry, 1970-94. International Journal of the Economics of Business, 7(3), 245-261. https://doi.org/10.1080/13571510050197177

Ha, H. Y., John, J., Janda, S., \& Muthaly, S. (2011). The effects of advertising spending on brand loyalty in services. European Journal of Marketing, 45(4), 673-691. https://doi.org/10.1108/03090561111111389

Hadadi, K., \& Almsafir, M. K. (2014). The Impact of Online Advertising on Proton Sales among Expatriates in Malaysia. Procedia - Social and Behavioral Sciences, 129, 274-281. https://doi.org/10.1016/j.sbspro.2014.03.677

Kwoka, J. E. (1993). The Sales and Competitive Effects of Styling and Advertising Practices in the U.S. Auto Industry. The Review of Economics and Statistics, 75(4), 649-656. https://doi.org/10.2307/2110018

Maclnnis, D. J., \& Jaworski, B. J. (1989). Information Processing from Advertisements: Toward an Integrative Framework. Journal of Marketing, 53(4), 1-23. https://doi.org/10.2307/1251376

Miremadi, A. (2012). The Impact of B2B Buying Behavior On Customer Satisfaction Within Shahab Khodro Company. International Journal of Business and Management, 7(7).

Ndubisi, N. O. (2007). Relationship marketing and customer loyalty. Marketing Intelligence \& Planning, 25(1), 98-106. https://doi.org/10.1108/02634500710722425

Nikhil, M., \& Bhunvender, C. (2012). Car Market and Buying Behaviour- A Study of Consumer Perception International Journal of Research in Management. Economics and Commerece, 2(2).

Rajagopal. (2006). Brand excellence: Measuring the impact of advertising and brand personality on buying decisions. Measuring Business Excellence, 10(3), 56-65. https://doi.org/10.1108/13683040610685793

Rajagopal, \& Gopal, R. (2007). Brand Management: Strategy, Measurement and Yield Analysis: Nova Science Publishers.

Saunders, M., \& Thornhill, A. (2007). Research Method for Business Students. UK: Prentice Hall.

Shimp, T. A., \& Andrews, J. C. (2012). Advertising promotion and other aspects of integrated marketing communications (7th ed.): Cengage Learning.

Srivastava, E., Srivastava, E., Maheswarappa, S. S., Maheswarappa, S. S., Sivakumaran, B., \& Sivakumaran, B. (2017). Nostalgic advertising in India: a content analysis of Indian TV advertisements. Asia Pacific Journal of Marketing and Logistics, 29(1), 47-69. https://doi.org/10.1108/APJML-10-2015-0152 
Turner, J., Hojjat, A., Cetintas, S., \& Yang, J. (2016). A unified framework for the scheduling of guaranteed targeted display advertising under reach and frequency requirements. Operations Research.

Vakratsas, D., \& Ambler, T. (1999). How advertising works: what do we really know? The Journal of Marketing, 26-43. https://doi.org/10.2307/1251999

Vikram, S. (2014). Analysis of Research in Consumer Behaviour of Automobile Passeneger car Consumer International Journal of Scintiffic Research and Publications.

Shimp, T. A., \& Andrews, J. C. (2012). Advertising promotion and other aspects of integrated marketing communications (9th ed.): Cengage Learning.

\section{Copyrights}

Copyright for this article is retained by the author(s), with first publication rights granted to the journal.

This is an open-access article distributed under the terms and conditions of the Creative Commons Attribution license (http://creativecommons.org/licenses/by/4.0/). 